\title{
THE MYSTERY OF CASPAR HAUSER (1956)
}

Bereits zwei Jahrzehnte vor Herzogs internationalem Filmerfolg wurde dem amerikanischen Fernsehpublikum die Hauser-Mythe durch Das Geheimnis von Caspar Hauser vorgestellt. Wohl auf Wassermanns Roman basierend, der 1928 erstmals ins Englische übersetzt in New York erschien und seither vielfach nachgedruckt wurde, produzierte das Hollywood-Studio Quintex Entertainment den Film für die Serie "Telephone Time" des Senders CBS. Als Caspar Hauser erschien Michael Landon in seiner ersten größeren Rolle. Dem deutschen Publikum wurde Michael Landon bekannt als >Little Joe in der Westernserie Bonanza.

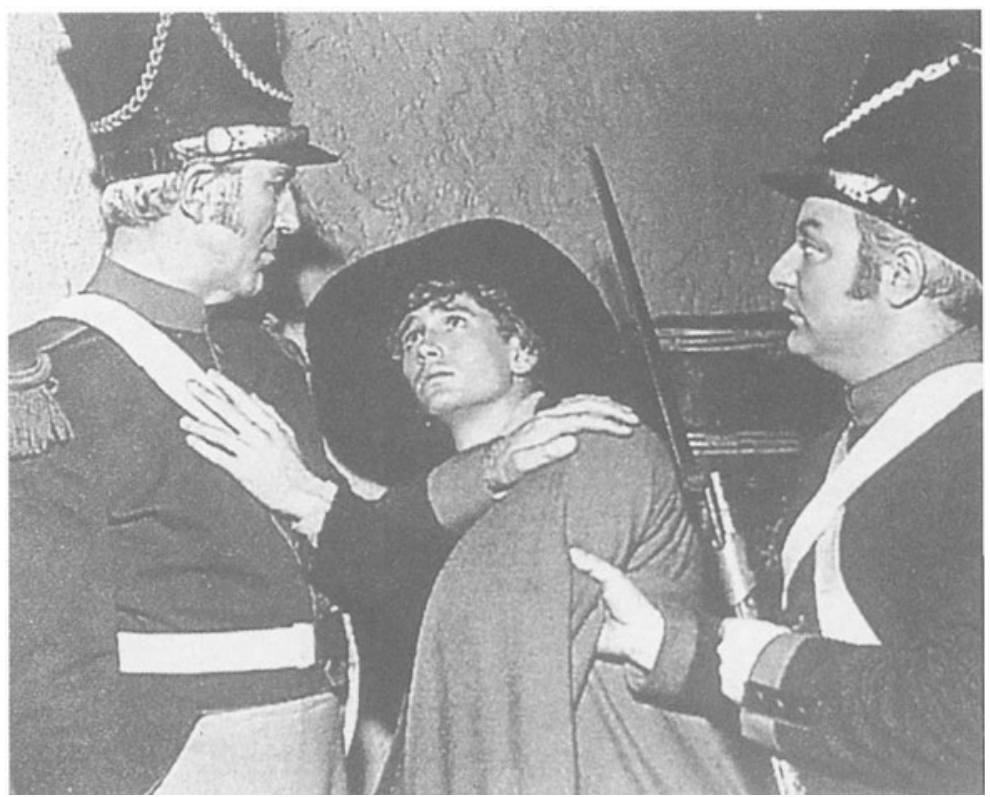

Caspar Hauser (Michael Landon) wird von der Nürnberger Polizei verhaftet. 